\title{
THE COLOMBIAN CITY OF MEDELLÍN: DISCUSSING THE IMPACT OF SOCIAL URBANISM
}

\author{
Ewelina Biczyńska (D) \\ Faculty of Geography and Regional Studies, University of Warsaw \\ Krakowskie Przedmieście 30, 00-927 Warsaw: Poland \\ ewelina.biczynska@gmail.com
}

\begin{abstract}
While the Colombian city of Medellín used to be infamous as the world's most violent (1991), a more recent image is as the most innovative (2013). The case of Medellín is thus taken to epitomise possibilities for positive change, with the city being looked up to by others. The particular renown here is as one of the cradles of the so-called 'social urbanism', an approach to city-making that aims to resolve social issues by means of interventions in urban space, via infrastructure, public places, etc. However, while the successes of this approach have been acknowledged and vaunted internationally, certain lesssuccessful effects have often tended to be silenced. This paper therefore focuses on the more-shadowy side to social urbanism, and on ways of proceeding that remain in place despite the transformations announced. The aim is thus to contribute to a fact-based discussion on the actual effectiveness of social urbanism in addressing social challenges.
\end{abstract}

Keywords: gentrification, Medellín, social urbanism, urban transformation.

\section{Introduction}

Many, and not least the author of this article, have been amazed by the 'miracle of Medellín'. A downward curve for homicides in what was once the world's most violent city, and beautiful architecture in districts nobody would have stepped in before, had to make their impression; and make it they did. And, over a number of years following the revolutionary 2004-2007 term of Mayor Sergio Fajardo, Medellín has come to arouse the interest of dozens of academics and journalists. Equally, while at the end of the first decade of the 21st century it was still positive voices about the city's transformation that dominated, today we mainly see more critical perspectives aired. But while 'the social urbanism' that is then the ultimate subject matter of this paper has been advocated for loudly, as a problem-solving tool targeted at improving quality of life among the lowest classes in society, fair research on its actual impact has been surprisingly sparse. This article therefore seeks to make its contribution to answering the key question as to how social urbanism actually proved impactful, and for whom; with this problem being linked into a broader discussion on the contemporary functioning and conditioning of cities, as well as their interrelations with inhabitants.

The means proposed for achieving these objectives entail a review of existing literature (as focusing on detailed research into Medellín's urban interventions), existing quantitative data collected by units of the administration, and the author's own qualitative and quantitative study pursued 
in Medellín in 2017 and 2019. Later sections deal with the theoretical background underpinning further considerations, with a close look taken at the city's history (as focused on the social component), projects implemented under the banner of 'social urbanism' reviewed, and available data on social and economic development analysed.

\section{Methodology}

More specifically, the methods and sources of data serving this article's purposes have included:

- available quantitative data coming from the Mayoralty of Medellín, the Colombian Statistical Office (DANE), the Agency for Cooperation and Investment (ACI) of Medellín, local and regional programmes of tracking research, and other open-access sources;

- the author's own quantitative data from a survey conducted in selected areas of Medellín from March through to June 2017 (with the sample of 264 interviews including 83\% representative of social stratum (estrato) 1 and $14 \%$ representative of stratum 2 - these being the two poorest groupings in society; and with $1 / 4$ of the sample relating to social housing, while the remainder derived from the traditional neighbourhoods);

- qualitative research and observations from the same period.

All interviews and observations from the author's original study are based on neighbourhoods of District (Comuna) 8, i.e. Sol de Oriente, Villatina, las Golondrinas and el Faro; District (Comuna) 7, i.e. las Margaritas and Olaya Herrera; District (Comuna) 13, i.e. la Divisa and Juan XXIII; the municipality of San Cristobal (social housing); and the urban development areas of Aurora Pedregal Alto and Tirol 2.

\section{The built environment and impact on quality of life}

'It might seem that cité and ville should fit together seamlessly: how people want to live should be expressed in how cities are built. But just here lies a great problem', points out R. Sennet (2019, p. 2). 'Experience in the city (...) is much more often full of contradictions and jagged edges' (Sennet, 2019, p. 2). While cité is the word Sennet uses for the urban lifestyle, customs and mentality, the context further on in his book would allow us to simplify and associate the term with the live, human fabric. Ville on the other hand represents the 'built environment', broadly understood as including buildings and roads, but also urban design. The relationship between the two is seen as far from harmonious, but the mutual impact goes unquestioned. The 1960s (J. Jacobs and K. Lynch) and 1970s (J. Gehl, the Project for Public Spaces) saw increased consciousness of, and interest in, the way in which the built environment actually impacts on people's quality of life and social interactions, and hence also the quality of communities.

Gehl (2011), as a 'guru and doctor' of public spaces made us see again what we had missed due to a kind of a 'home blindness' - that our cities have become functional, instead of liveable, car-dominated, boring and uniform; as they have been designed from a helicopter's perspective, without consideration being given to the eye-level experience.

The goal should be total treatment in which the city in its entirety - the skyline, placement of buildings and proportions of city space - are combined on the basis of careful treatment of space sequences, details and furnishing at eye level. (...) In many cases this ideal stands in contrast to a planning practice rooted in modernism, which focuses on building rather than 
holism and city space". (Gehl, 2013, p. 375).

This 'antimodernist foment' (Montgomery, 2013; p. 15) for decades brought a handful of evidence that the quality of urban space and built environment has its impact on human happiness (e.g. Dunn et al., 2003), the quality of human relations (e.g. Valins \& Baum, 1973), or even health (Sternberg, 2010; Montgomery, 2013).

In any case, those in charge of cities started paying more attention to the quality of urban space. Despite their sometimes facing very different challenges, cities in the Global North and Global South alike began to engage in more-systematic reflection on urban space, and to step in again to regulate the domain of developer companies. This discourse is in fact matched perfectly by the 'social urbanism' approach that is the backbone of this paper, gains further explanation below, and can be said to have been born in South America. That approach assumes that serious social problems, marginality and exclusion can all be addressed by means of territorial interventions (Echeverri \& Orsini, 2010).

As new urban policies came to focus more on transforming cityspace, the proper measurement of their results became increasingly important. Measurement of Quality of Urban Life is becoming a must-have for self-conscious and improving metropolises; and Quality of Life indicators are evolving in the direction of Quality of Urban Life indicators (Marans, 2012; Ballas, 2013). It is then in line with these that rankings are developed (Ballas, 2013); and no city-dweller or manager would like to find their city placed at the bottom. Indeed, a good position can translate into real-life financial stimulation of business or tourism. Many other institutions have come up with their own rankings, based on variables selected subjectively; while new online platforms allow people from all over the world to rank places and cities, and gain easy access to statistics based on millions of reviews. The city is being evaluated in annual tracking research programmes, as well as in real time - by visitors and inhabitants alike.

However, greater consciousness, and bottom-up struggles to improve the space in which we live, coincide with a neo-liberal turn in which cities became the poles of economic development (OECD, 2006), and started to compete in the global network of metropolises, in some sense ignoring state borders. As Jenny Sierra Noreña puts it, interpreting Régis Debray's 'Seductive State', under 'the logics of competition, profitability and the commodification of life, the State has been forced to become included in the dynamics of advertising and marketing' (2016, p. 127). In Jodri Borja's words, it is supposed to sell itself to investors and companies in a manner that is 'as cheap as possible' $(2001$, p. 1). Such marketing activities engaged in by regions and cities are supposed to attract capital, in the form of direct and indirect investment. Apart from enterprises, tourists are further addressees of these 'advances'.

These quite new functions, opportunities and duties that cities have, lead to changes of a city's 'skin', of its physiognomy; but also of the social structure of certain places, which is not less than a gentrification (as defined by this term's author, Ruth Glass, 1964). Another face of gentrification is encountered in cities that decide to sell themselves to growing groups of tourists, as there is ongoing 'touristification', i.e. an 'increase in tourist activity that generally implies the loss of residents' (Jover \& Díaz-Parra, 2019, p. 1). In the case of Medellín, Mary Roldan (1997) even used a term the 'miamisation of architecture'. Miamisation used to be a term for internationalisation, via Miami, of Latin-American products of culture (mostly music and film), in order for them to be sold more readily to a Global-North client (Party, 2008).

All three processes - gentrification, touristification and miamisation - aim at changing urban spaces in a way that leaves them attractive to other, new target groups characterized by higher (than current-user or dweller) purchasing power or investment potential. None of these dynamics 
are unfamiliar to Medellín - indeed, why would they be, if Latin-American cities have been introduced so firmly on to the global market (Franz, 2017)?

\section{Medellín's location}

The Colombian City of Medellín is located at an altitude 1479 m above sea level, in the Aburrá Valley, in the Cordillera Central of the Andes. On account of its mild climate, it is known as 'the city of the eternal spring'. Only more recently did this locality achieve metropolis status, with the 70 years from 1938 bringing an increase in population from 168,000 to the current ca. 3 million within the metropolitan area. Needless to say, this population remains a relatively young one, with almost $70 \%$ of all inhabitants aged between 5 and 44 . Medellín is Colombia's second city after the capital Bogotá, and is itself the capital of Antioquia Department, one of Colombia's wealthiest.

Due to the very specific nature of the terrain here, the density of population is extremely high $-2,300$ inhabitants per $\mathrm{km}^{2}$ (UN, 2018), and still rising. A majority of inhabitants face slopes that are too steep to allow houses to be built. Dissected by many ravines and gorges, the city has 7 hills within its limits that separate groups of people from each other (even in the face of the extremely high population density), with the effect being to further fuel both marginalisation and exclusion.

Perhaps paradoxically, the high density of population and direction of growth are taken as assets by city-makers (KienyKe, 2017). Always up-to-date with the latest trends in urban planning, they underline how Medellín's development as a compact city is a positive phenomenon, even though that is forced (or at least stimulated greatly) by the topography referred to above. Indeed, spatial features like location, topography or climate have marked Medellín's fate significantly. Thanks to its location at mid-altitudes in the Tropics, it enjoys a mild and balanced climate. It is on the edges of the café region of several Departments in central Colombia whose culture is based around an entrepreneurial spirit and a dense network of formal and personal ties. In more recent times, a location close to fertile soils and commercial routes, in the Andean region very suitable for coca planting, but close to the Caribbean and not so far from the USA, made it ideal for acquiring the status of 'capital' of the trade in cocaine. As the largest urban centre in a region affected drastically by the period of La Violencia ${ }^{1}$ (and also with industry still developing dynamically), Medellín became the immigrant destination of choice (or in fact no choice), for hundreds of thousands of newcomers. Thus, while Medellín shared many characteristics with other Latin-American cities as it entered the era of modernisation, it also had certain specific and individual characteristics.

\section{A golden child of industrialisation}

Through to the end of the 19th century, Medellín only developed rather slowly, becoming the capital of Antioquia Department in 1826. The first impulse for its economy to develop was supplied by gold and coffee, respectively extracted and cultivated in the region, and also sent for export. Medellín served as a centre of commerce where these and other goods were concerned; and with hard-working inhabitants it entered an era of growing prosperity. What is more, money made in international trade tended to funnel into the founding of new branches of Colombian industry (Sánchez-Jabba, 2014).

\footnotetext{
${ }^{1}$ La Violencia (The Violence) in Colombia refers to a civil war raging from 1948 through to 1958 , between supporters of the Conservative and the Liberal Parties. It was mainly fought in the countryside and cost approximately 200,000 people their lives.
} 
This allowed the state to transit from near-total dependence on primary resources for its economy into an industrialisation phase only reinforced in the 1930s and 40s as an 'Import Substitution' approach was taken. The partially wartime period 1930-1945 brought unprecedented expansion in Colombia's manufacturing industry, with the textile sector leading the way. Medellín was Colombia's principal centre of the textile industry. As of 1947, 17.3\% of all Colombia's employees in industry worked in the city, with the capital Bogota (a far larger city) only in second place on $15.7 \%$ (Sánchez-Jabba, 2014, p. 226).

Medellín's economic and urban development served as an impetus for a sense of civic pride. 'Antioqueños have historically thought of themselves as a culturally distinct group of no-nonsense, driven, industrious, devout and efficient individualists, and of Medellín, the region's capital, as the urban embodiment of regional identity and pride' (Roldan, 1997, p. 2). Dominating values of the paisa - the 'original' inhabitants of Medellín and the region - were based around Catholicism, but leavened by a renowned entrepreneurial spirit, courage and a 'keep going forward' attitude.

It is often recalled how the capital of Antioquia drew its economic strength from unusual solidarity and close ties between the most powerful families forming the elite. Holding both economic and political power, these were key drivers of ways in which the city changed and evolved, transforming its physical aspect but remaining faithful to rather traditional Christian values of charity, decency, good manners, etc. (Naranjo \& Villa, 1997). These elites also paid great attention to how their city was perceived, and they garnered praise for its infrastructural development, cleanliness and modernity of construction. A high level of cohesion between the public and private sectors helped assure the achievement of infrastructural development ostensibly desirable for all, if benefiting the wealthy entrepreneur class first and foremost.

As the decades passed, the same developing industry proved a huge draw and pull factor underpinning unprecedented migration out of rural areas. At first this was driven by rural poverty and the search for new opportunities the city had to offer; but it was soon followed by a severe push factor reflecting La Violencia - a bloody conflict between Conservative and Liberal supporters that consumed whole families caught up in it, or motivated people's flight to the city in bids to save their own lives.

The consequence was a doubling of the population of Medellín in the 1950s, and an established trend that did not wane with further decades of changed circumstances. A robust rate of natural increase only served to further this process, whose result was to leave simply no more room for a working class of largely peasant origin that kept on coming. The city began to sprawl wherever that was possible, Medellín soon witnessing the appearance of informal, self-constructed housing, in the central as well as peripheral parts of the city. However, the terrain by no means facilitated such settlement, as more-elevated and steeper-sloping pieces of land were almost all that were available. The middle and upper-middle classes came up with charity housing for workers, which soon emerged as insufficient. As early as in the 1950s, a city famous for its public services (and home to the prospering EPM company ${ }^{2}$ ), began to strive to outfit its new settlements with water supply, sewerage, etc.

The integration of incomers with the dominating culture and those who represented it proved by no means easy. Despite sharing largely-similar values as regards self-determination, courage and freedom, the immigrants have been of different ethnicity, religion, life experience and (perhaps first and foremost) economic status (Patiño-Villa, 2015, p. 72). And, in the eyes of the middle class, material and economic poverty have become linked closely with mental and moral shortcomings that from the very beginning prevented various communities from achieving any inte-

\footnotetext{
${ }^{2}$ EPM (Empresas Publicas de Medellín) is a state-owned, industrial and commercial enterprise (composed of 12 companies), owned by the municipality of Medellín. It provides the services of electricity, gas, water, garbage collection and telecommunications.
} 
gration at all. The poor and marginalised population was further associated with delinquency and moral corruption.

The image of Medellin (...) began to be contaminated by the presence in the city of migrants

(...) who had other cultures, who did not belong to the mercantile economy (...). Medellin began receiving those excluded from the paisa model. (...) All these city-dwellers began to inhabit the city, but without becoming citizens. It did not take long for urban marginality to become a widespread phenomenon (Patiño-Villa, 2015, p. 74).

It was in this period that talk first arose about Medellín being 'two cities' that never met. The lack of good, safe and accessible public spaces, for instance in an identifiable city centre, did not facilitate such an encounter. Indeed, tensions between the cité and ville started to become more and more painful.

\section{Crisis and breakdown}

Medellín spent the following decades from the 1950s through to the 1970s reinforcing its position as Colombia's second-largest economic hub. However, it was a high degree of specialisation in textiles that determined how severe the later economic crisis would be. More-open trade and the end put to Import Substitution Industrialisation in the 1970s allowed for an eruption of fierce competition of local industry - against imported goods, textiles and shoes in particular. At the same time, smuggling had come to be a widespread practice that only jeopardised local industry still further (and indeed that of Medellín more than elsewhere) (Kalmanowitz, 2015). This all resulted in hitherto-unseen levels of unemployment, and worked to reinforce the informal and illegal economies (Museo Casa de la Memoria, 2018).

It had been in the somewhat earlier period of the 1960s that the private sector had begun to withdraw from its traditional activity in the public sphere. In 1968, those administering the city came out with an official act barring public-service companies from extending any of their activities into the informal settlements located beyond Medellín's city limits. The city was developing in a way that strived to favour the middle class and elites, with investment in major infrastructural projects and roads, often actually installed in such a way that contact with shanty towns could be better avoided (MacLean, 2014). By the 1990s, such growing examples of people's backs being turned on the poor would come to be referred to as a 'social debt' that the rich had with the latter. As so often, however, it took a tragedy to bring any more open confession. The 1970s brought an economic slowdown and crisis, even as newcomers kept arriving. Medellín's industry was no longer able to provide employment for such masses.

The rate of unemployment thus rocketed in the 1970s; this coinciding with the appearance on the scene of new entrepreneurial actors in the shape of the drug cartels. And, towards the end of the 1980s and into the 1990s, drug-trafficking activity involved the cartel from Medellín in an open fight against the state associated with unseen levels of violence and homicide (see Fig. 1).

The Medellín Cartel inevitably recruited members and contractors from among the poorest and youngest male inhabitants of the city's marginalised districts (mostly, though not exclusively, in the north-east). Notwithstanding the lack of any formal declaration of war, the city had been turned into a battlefield. Its image as the most violent place in the world aroused fear, and this represented a further barrier to ongoing economic development. At this stage, almost everyone suffered - the poor; members of the middle class who would remain shut in their homes after dark; but also the elites who saw their businesses threatened. 


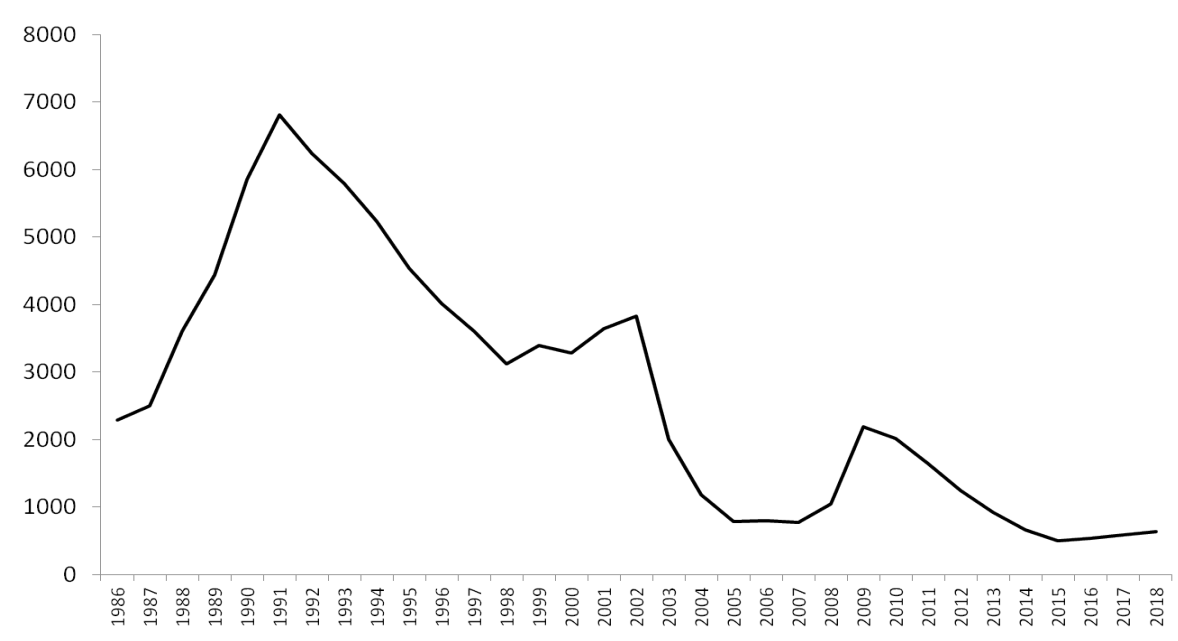

Figure 1. Number of homicides in Medellín Source: Martin (2012).

The drugs trade was primarily responsible for the first wave of homicides, whose numbers rose dramatically from the mid-1980s through to a peak in 1991 (when Medellín indeed took the record as the world's most dangerous city). However, it was not too long before the status of most violent actor was taken on by paramilitaries operating in so-called self-defence. It was their ultimate demobilisation in 2003, as well as greater coordination among the delinquent, that finally allowed Medellín to see peace and positive transformation somewhere on the horizon.

\section{Turning point}

The violent crisis that was drenching the city in blood afforded an uncommon opportunity for representatives of various social groups to integrate in search of a unified solution. This then is what some researchers refer to as a critical juncture (McLean, 2014), as

moments of relative structural indeterminism when willful actors shape outcomes in a more voluntarist fashion than normal circumstances permit (...) these choices demonstrate the power of agency by revealing how long-term development patterns can hinge on distant actor decisions of the past (Mahoney, 2002, p. 8).

What was in effect a 'civil war' led to encounters not seen before, as bombs exploded in areas hitherto spared the violence of greatest intensity. In turn, young boys involved in the drug business could potentially garner such insane amounts of money that access to luxury spaces in the city that they would never otherwise have visited, became an option (Roldan, 1997). This was therefore a serious disruption of an order previously set and fixed in the city, even notwithstanding the huge inflow of immigrants going unintegrated with the paisa living in Medellín for generations; with the city's territory demarcated by borders that were invisible, but fully recognisable in the community.

For middle- and upper-class residents represented by Medellin's captains of industry and local authorities such as former Medellín Mayor and ex-Governor of Antioquia, Juan Gomez Martinez, the darker view of Medellin is the product of a recent (atypical) phenomenon, the international narcotics trade and its corruption of the city's 'traditional values'. More 
specifically, the corruption of local values is attributed to the criminal organisation lead by Pablo Escobar and an urban underclass which is perceived to have constituted Escobar's and the narcotics trade's principal base of support. In fact, regional and local officials explicitly locate the epicenter of urban violence in the comunas nororientales - the poor north-eastern section of the metropolitan area where the majority of the city's assassins and gangs are perceived to reside. (Roldan, 1997, p. 3).

Nobody therefore doubted that Medellín needed change, even though the motivations underpinning this belief might be very varied indeed.

\section{The birth of social urbanism}

The definitive failure (lack of desired effect) of large economic interventions of national reach implemented in many countries from the 1950s through to the 1970s caused the eyes of economists to turn to smaller, measurable and manageable programmes of assistance and development (Leszczyński, 2016). The 1980s and 1990s thus saw a shift of approach towards the latter; and it was in this context that Medellín resembled many other places in noting first integrated projects seeking to achieve quality- of-life improvements. At the same time (i.e. with the late-1970s' new development agenda driven by the Washington Consensus), there was a transformation in local-governance practices in a spirit of neo-liberalism. This meant a focus on 'market-driven development through financial and trade liberalization, a roll-back of the state, emphasis on increasing business confidence, and the flexibilisation of the labor market' (Franz, 2017, p. 54). The city became an operations centre and hub for the economic development of the wider state, and needed to attract business and investors in line with the pursuit of this kind of role.

Although social urbanism and Medellín's recognition as a city-star of transformation were impacts of the 21st century, first relevant programmes for integral interventions in poor neighbourhoods and the implementation of participation tools had come along in the 1990s. However, as pilot programmes these covered certain, selected areas of the city, and were much 'quieter' and less monumental than what came later (Betancur, 2007).

The fight against violence and positive change in the image of the city characterising the early 21st century would not anyway have proved possible without a number of actors, processes and efforts, including the interest and help of the central government, but also a new political Constitution from 1991 that favoured decentralisation and put more decision-making into the hands of regional and local policymakers. What is more, after a period of disinterest and a certain distancing from public affairs, the private sector once again became active, sitting down to the mediation efforts, and then going on to take action. Soon, the world would see the official birth of the so-called social urbanism; and come to be fascinated by the transformation Medellín was going through.

It was Sergio Fajardo - the city's Mayor in the years 2004-2007; as well as his right-hand man - architect Alejandro Echeverri, that were the first icons of the new trend in designing cities. Social urbanism is a city-making approach developed in Medellín from 2000 onwards as part of the Medellín Model. It has had as its goal a triggering of social transformation by virtue of urban intervention. Social urbanism entails, basically

directing large investments to specific urban projects located in the city's Comuna Popular. Arguing that the city owes a historical debt to these forgotten sectors, the policy has opted to pay that off through the construction of infrastructure and architecture of high quality and strong aesthetic and social impact (Brand, 2009, see also: Duque Franco, 2015). 
The approach, though subject to evolution, has been kept up in the policies of successive Mayors, with Ánibal Gaviria (2012-2015) for example inspired by a pedagogical urbanism approach, and thus seeking to strengthen processes and tools by which citizenship could be built, roots put down, neighbourhood synergies consolidated, and continuity injected into urbanism and to the process of social, economic, environmental and governance transformation (Ortiz \& Liebherr, 2014; UN, 2017).

The first decade of the 21st century brought a transformation that could not go unnoticed. Some of the most-major projects to change the face of the city encompassed the system of parks, as locations of new libraries and public-use buildings brought into the poorest areas, and beautifully equipped and provided with animation. Then there was the renowned and innovative cable-car system serving mass transport, by linking marginalised neighbourhoods with the city centre and the Metro (the first and only such railway in Colombia). New schools, centres of business development, police and security stations were built, and public space and the streets came under special care and were renewed. The idea was to encourage people to leave their homes once more, with social ties in this way reinforced, and security and the joy of life improved. This indeed happened, with a sudden, marked fall in the homicide rate soon noted (Insight Crime, 2019). A peak of success was perhaps reached in 2013, when Medellín was awarded the title of world's most innovative city.

A more-detailed description now follows, of the most-renowned new developments and initiatives characterising the first years of social urbanism. Parques-bibliotecas is a (currently 9-unit) chain of multi-functional libraries, digital-education and digital-inclusion centres that also focus on art, the animation and education of children, social integration and cohesion. From the outset, the matter of the locations of these centres was emphasised strongly, given the key assumption of the social-urbanism principle: that construction should start in the districts where incomes are lowest, poverty rates highest, and the stigmatisation arising out of the violent past most marked. From the very beginning, then, strategic objectives of different institutions were brought together, to help the social fabric grow and to ensure that a new kind of lifestyle could be proposed. In essence, a Library-Park is an urban space designed to achieve simultaneous educational, cultural and social improvement (Peña Gallego, 2011). Beyond these statutory goals, the matter of buildings' architectural designs has also been extremely important. Two such projects to be mentioned in first place are the 'Library-Park of Spain' and 'Library-Park in Belen'. The former name reflects the economic contribution from the Spanish Royal Family; and indeed the development was inaugurated in 2007 in the presence of King Juan Carlos, in what might have been the first sign that the eyes of the world on the transformation of Medellín. Real change was still not too tangible back then, with the result that the surprise and enchantment were all the greater. However, soon after that, the building - raised in a hurry and with numerous modifications vis-à-vis the original design - began to break up (Gonzalez Escobar, 2014). Through to 2019, reconstruction work was ongoing, though - while the monumental building is not in fact in use - the Library-Park is in operation as an institution, with animation work and other activities ongoing among neighbourhood inhabitants. The Library-Park in Belen is in turn to a design by a group of architects from the University of Tokyo, and proves fascinating from the point of view of its harmonious 'synthesis between Shinto temple and local courtyard (patio) house' (Gonzalez Escobar, 2014, p. 111-112).

The cable car known as the Metrocable was to offer a new stimulus for mass transit, was opened in 2004, but remains in development. At the time of writing, it had 6 lines with 15 stations altogether. This is a means of transport tailor-made for Medellín, given the way the system spans the space from one surrounding hillside to another. In line with the principles of the sustainable city, the development seeks to reduce congestion, and does do so (Dávila \& Daste, 2012); and 
actually represents a fast way of moving from peripheries into the city centre. Moreover, from the very outset, huge social impact was ascribed to the Metrocable project. Much can be read into a Business Insider article title: Here's what it's like to ride Medellin's famous cable car system, which helped transform the Colombian city from the world's most dangerous to the most innovative (Baker, 2019). The same article uses the word 'symbol' a number of times, as it seeks to underline the importance of this cable-car system. A further stated belief is that Metrocable transformed the city and its culture (Medellín, 2008); and there can be little doubt that perceptions of the city have been changed by what has become an iconic feature, tourist attraction and reason for civic pride among city-dwellers. On the official tourist website, we read: 'Although designed specifically for locals, the cable cars are now Medellín's no.1 tourist attraction, giving visitors a view of barrios populares (favelas) from an interesting and up-close perspective' (MC, 2019). In a survey run among approximately 250 inhabitants of Medellín from the poorest neighbourhoods, Metrocable was found to be one of the attractions worth presenting to a newcomer or tourist that were mentioned most frequently (Table 1 ).

Endeavours or undertakings of the Integrated Urban Project (PUI) type were inspired and introduced by Sergio Fajardo, the Mayor of transformation, and they represented a further shift in the approach to city-making. A PUI is an urban intervention instrument with material, social and institutional dimensions, that seeks to solve a specific problem identified in a particular area. There is a certain methodology involved, i.e. a model for dealing with areas of unplanned growth, limited coverage when it comes to infrastructure, and a shortage of public spaces (AP, 2019).

[In traditional governments], each agency, each Secretary, each Ministry is, in a majority of cases, an island administered by a political group; and at all costs they avoid working together so that the importance of one is not overshadowed by that of others; or so that they don't become distracted from a particular interest when they dedicate themselves to a common objective. We, on the contrary, were committed to our collective political plan; we didn't have individual projects, we wanted to get integrated and work together; and this made a huge difference in public administration. The connectedness associated with having one common vision breaks with the tradition of isolated actions, and this integration is our contribution to politics. This is how Integrated Urban Projects - the PUIs that probably represent the deed I am most proud of-were born. (Fajardo, 2017, p. 113).

Table 1. Places in Medellín worth showing to visitors, in the opinion of estrato- 1 and 2 inhabitants

\begin{tabular}{|l|c|}
\hline \multicolumn{1}{|c|}{ Place } & $\begin{array}{c}\text { Percentage } \\
\text { of respondents }\end{array}$ \\
\hline Jardin Botanico (the Botanical Garden) & 27 \\
\hline Parque Arvi (Arvi Park) & 26 \\
\hline Pueblito Paisa (the replica of a historic town in Antioquia) & 26 \\
\hline Metrocable & 23 \\
\hline Parque Explora & 21 \\
\hline Metro (the underground railway system) & 19 \\
\hline Botero/Parque Botero (a park featuring Fernando Botero sculptures) & 17 \\
\hline Base & 254 \\
\hline
\end{tabular}

Source: author's own elaboration. 
The first PUI was implemented in the aforementioned north-eastern part of the city, i.e. one of the least-developed, enduring the highest rates of poverty. Part of the effort was a station along the Metrocable, as well as what is probably the best known Library-Park - the aforementioned Library-Park of Spain. However, there is also a health centre, high-quality school, and centre for the development of entrepreneurship (Cedezo), as well as public spaces, street renovation work, parks, viewpoints and pedestrian bridges.

The second PUI involved the zone called Moravia, a group of informal neighbourhoods constructed over an old landfill. Apart from a health centre, parks, schools, and a beautiful and modern culture centre, the project involved rehousing for a number of families. In the first phase of this, some 2500 families were moved out of Moravia into new, multi-family housing close by, or else further out on the peripheries. The second phase involved 1689 families, who were moved to an extensive district of social housing called the Ciudadela Nuevo Occidente (Osorio Gaviria, 2014). This will be referred to further a few paragraphs on from here. In general, the PUI became a model by which the city might achieve transformation in an integrated and holistic way.

Colegios de Calidad - Medellín, la Más Educada ('Medellín, the most educated') represented the main theme of the first Mayor propounding social urbanism, Sergio Fajardo. We might guess that his strong focus on architecture was inspired by his parents, and especially his father - Raul Fajardo Moreno, who is a famous architect known inter alia forth the iconic Coltejer building which is shaped like a sewing machine needle. In truth, though, Fajardo is a mathematician, and professor, who graduated from Universidad de Los Andes (probably the best in Colombia), and also has extensive academic experience in the USA. Education has been his obsession, looked upon as a tool by which to fight against the most severe social problems, like poverty, exclusion and violence.

Giving effect to his principle that the best buildings be put into the poorest neighbourhoods, the Quality Schools were new public colleges designed by the best architects, yet located in peripheral and poor neighborhoods, supplied with qualified staff and opened up to the community (Salazar Jaramillo, 2011). During Fajardo's term, 10 such Quality Schools were designed - and made available to pupils from 2008 on. This programme was financed by EPM, via a decision of its Board of Management, which had initially wanted to sponsor a new Park. However, Fajardo had insisted that EPM's resources be directed into education. The 'Medellín, the most educated' Programme also included improvement of already-existing schools, a new system of kindergartens (Buen Comienzo) and a scholarship for students in higher education.

Fajardo's term also set new standards for transparency and credibility, with corruption and the 'culture of illegality' also combated (Fajardo, 2017). Later incoming mayors with their administrations thus had the bar set high for them, but acted in the spirit of continued social urbanism.

Simultaneously with these changes, and in the circumstances of coordination at national level, a huge public relations and marketing campaign was launched. Since 2005 , Colombia has been running marketing campaigns financed by the Export Union and the private sector. Medellín continued with this trend successfully, its campaigns focusing on the miraculous nature of its transformation, and seeking positioning on the market as a hub for innovation and a laboratory for positive change.

\section{Noticeable effects}

From the early 21st century on, certain independent researchers joined city officials in seeking to evaluate the effectiveness of all Medellín's new developments targeted at improving quality of life and reducing disparities in society. Surveys, the development of objective quantitative indicators 
and evaluations of particular new developments all helped shed light on the true effectiveness of social urbanism, its particular programmes and concrete initiatives.

Medellín impressed the world with its amazing transformation, above all visible in a decline in levels of homicides and violence. The figures speak for themselves in showing a rapid calm-down at the beginning of the 21st century (see Fig. 1). Its simultaneity with the birth of social urbanism combined with direct and open claims that the latter was indeed responsible for this impact - were what helped to link the two, and incline others to believe in the real agency architects might enjoy when it came to solving severe social problems. 'I'm reducing crime with urban planning', would say Alejandro Echeverri, the aforementioned right-hand man of Sergio Fajardo, and an architect strongly involved in laying down the groundwork for social urbanism in the context of the installed cable-car station in Comuna Popular in the north-east of the city, one of the poorest districts, affected most severely by the violence (Echeverri, 2019).

The truth is that the processes involved and ongoing were far more nuanced and complex. But prior to any more-detailed reference to the factors that made the calm-down possible, it is worth recalling how - as has been noted already, the majority of homicides taking place towards the end of the $20^{\text {th }}$ century and at the very beginning of the 21st might in fact be attributed to paramilitaries. On the one hand, these violent groups emerged as the inheritors of illegal business once run by the drug cartels. But on the other hand they derived from self-defence groupings organising to try and safeguard against such crime. It so happened that they mostly represented a conservative (i.e. anti-leftist) worldview, and as such gained the tacit support of the State (CNMH, 2017).

It was the period between 1995 and 2005 that featured an armed conflict between paramilitary organisations (one against another), but also between the latter and other militia and guerrilla (leftist) organisations. The city was also on the receiving end of a more forceful military intervention on the part of the state. Armed conflict thus resulted in a total of 52,004 victims of violence. However, 2003 finally brought official (state and legal-authority-supported) action to ensure the demobilisation of members of paramilitary groups (CNMH, 2017; Soto, 2012).

The whole process which led to reduced crime included more definitive war against the leftist guerrillas but also greater coordination in the territorial control of criminal organisations (Moncada, 2016). In other words, it is not the case that the latter have simply disappeared, just as it is not the case that illegal business has disappeared. Rather, both have changed their modus operandi, not least thanks to their uniting under the rule of one mighty leader, Diego Murillo, alias Don Berna. However, following his 2008 extradition to the USA, the unity of the criminal groups weakened once again, and there was something of a relaunch of the fighting to gain territorial control and grab illegal revenues. This immediately found its reflection in numbers of homicides (García, 2018). Given that fact, it becomes still-harder to link the earlier, sudden decrease in homicides too closely with spatial interventions.

Leaving architects' tall-talk aside, Julio Davila joined with Diana Daste (in 2012) and Peter Brand (in 2011) to engage in a persistent search for actual and measurable impacts of Medellín's cable-car system on the social and economic status of those dwelling close to its stations. With due academic seriousness and solidity, they first list the difficulties inherent in estimating a cable-car's impact on a local community. Clearly, a number of different circumstances exert a simultaneous influence on inhabitants' wealth and status. These include the economic situation at the given time and fluctuating levels of violence, but also the fact that other social programmes were being pursued, and interventions made, at the same time (not least the generalised urban improvement programme). Beyond that, relevant measurement and assessment of the situation prior to con- 
struction of the cable-car is lacking (Brand \& Dávila, 2011a). Notwithstanding these limitations, the researchers were in a position to reveal that:

- the cable car does not yield particular savings of either money or time, being mostly used by formal- economy employees who travel far;

- there is no particular contribution extending participation in the life of the city;

- the local economy and entrepreneurship have not been stimulated as expected.

'Our research confirms the increase in community self-esteem and the sense of inclusion that the cable-car systems and urban projects have produce' - the authors admit (Brand \& Dáavila, 2011a, p. 14, see also Brand \& Dávila, 2011b), in this way recalling other studies on urban interventions in Medellín, such as the one by Letty Reimerink (2017) relating to the electric escalator, which was ultimately shown to impact upon pride, but not much more than that. However, a reduction in emissions of $\mathrm{CO}_{2}$ is a proven result of the Metrocable system (Dávila \& Daste, 2012).

However, it is visible, even to the unaided eye, that the economic situation in Medellín has been improving in recent years - as is confirmed by poverty indicators that have seen a quite continuous and steady decrease from 2002 through to the present day. However, this positive tendency is present in all the major cities of Colombia (Table 2), and can mostly be associated with the development of the Colombian economy in the 21st century. The most stunning progress was made between 2002 and 2010, with a 2010 Newsweek article stating that:

(...) against all odds Colombia has become the country to watch in the hemisphere. In the past eight years the nation of 45 million has gone from a crime-and drug-addled candidate for failed state to a prospering dynamo. The once sluggish economy is on a roll. Oil and gas production are surging, and Colombia's MSCl index [Morgan Stanley Capital International measurement of stock market performance] jumped 15\% between January and June, more than any other stock market this year. (...) This is more than a bull run. Since 2002, foreign direct investment has jumped fivefold (from \$2 billion to \$10 billion), while GDP per capita has doubled, to $\$ 5,700$ (Margolis, 2010).

There has also been a gradual reduction in economic disparities expressed by reference to the GINI index (Table 3.), proceeding at the same pace as in other largest cities, and remaining high in comparison with European levels, for example (Vienna - 0.34, Berlin -0.29, Madrid -0.34, Prague -0.30; OECD, 2006).

On the other hand, the city authorities agreed that income-related variables should not be the only indicators used to measure progress and inequalities. Income and monetary poverty do not uniquely stand for quality of life, so various indexes which combine several dimensions of well-being are used to track the direction and pace of changes. The multi-dimensional index of life conditions, which includes variables relating to housing, public services, the environment, schooling, mobility, equipment, participation, security, health, work and recreation among other things, shows slow and fluctuating growth, and despite a positive trend does not portray any revolution. However, long-term improvement can be observed for the most-marginalised and lowest-class parts of the city (Table 4). And also some improvement e.g. in Comuna Popular as the first PUI was developed in this area (2004-2007/8 - project implementation). It needs to be also taken in mind, that the neighbourhoods of informal origin, like most in Comuna Popular also consolidate and upgrade themselves with their own, dwellers' efforts (see e.g. Samper, 2017). 
Table 2. The extreme monetary poverty rate index in the 4 largest cities in Colombia

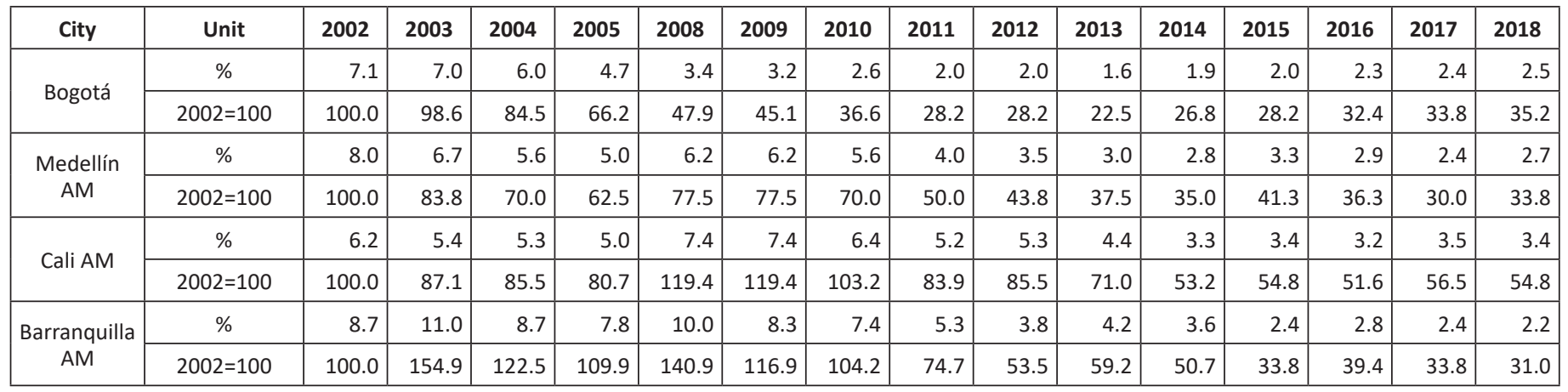

Source: author's own elaboration based on DANE (2019).

Table 3. Gini Index for the 4 largest cities in Colombia

\begin{tabular}{|c|c|c|c|c|c|c|c|c|c|c|c|c|c|c|c|c|}
\hline City & Unit & 2002 & 2003 & 2004 & 2005 & 2008 & 2009 & 2010 & 2011 & 2012 & 2013 & 2014 & 2015 & 2016 & 2017 & 2018 \\
\hline \multirow{2}{*}{ Bogotá } & Index & 0.6 & 0.5 & 0.6 & 0.6 & 0.5 & 0.5 & 0.5 & 0.5 & 0.5 & 0.5 & 0.5 & 0.5 & 0.5 & 0.5 & 0.5 \\
\hline & $2002=100$ & 100.0 & 95.6 & 97.7 & 97.6 & 93.0 & 92.1 & 92.1 & 91.4 & 87.0 & 88.3 & 87.9 & 87.2 & 87.4 & 87.2 & 88.3 \\
\hline \multirow{2}{*}{$\begin{array}{l}\text { Medellín } \\
\text { AM }\end{array}$} & Index & 0.5 & 0.6 & 0.5 & 0.5 & 0.5 & 0.5 & 0.5 & 0.5 & 0.5 & 0.5 & 0.5 & 0.5 & 0.5 & 0.5 & 0.5 \\
\hline & $2002=100$ & 100.0 & 101.8 & 98.9 & 95.4 & 99.3 & 97.8 & 98.4 & 92.7 & 91.4 & 92.5 & 96.2 & 89.4 & 87.4 & 84.8 & 86.7 \\
\hline Cali AM & Index & 0.5 & 0.5 & 0.5 & 0.54 & 0.5 & 0.5 & 0.5 & 0.5 & 0.5 & 0.5 & 0.5 & 0.5 & 0.5 & 0.5 & 0.5 \\
\hline \multirow{2}{*}{$\begin{array}{c}\text { Barranquilla } \\
\text { AM }\end{array}$} & Index & 0.5 & 0.5 & 0.5 & 0.51 & 0.5 & 0.5 & 0.50 & 0.5 & 0.5 & 0.5 & 0.4 & 0.4 & 0.4 & 0.4 & 0.4 \\
\hline & $2002=100$ & 100.0 & 102.1 & 101.0 & 97.2 & 94.7 & 92.1 & 94.1 & 89.4 & 87.9 & 86.7 & 84.3 & 83.1 & 82.0 & 83.3 & 83.9 \\
\hline
\end{tabular}

Source: author's own elaboration based on DANE (2019). 
Table 4. The multi-dimensional quality of life index for Medellín - in the city's wealthiest and poorest Comunas.

Source: MCV (2018).

\begin{tabular}{|l|c|c|c|}
\hline \multicolumn{1}{|c|}{ Communa } & $\mathbf{2 0 1 0}$ & $\mathbf{2 0 1 8}$ & Difference \\
\hline Poblado & 77.0 & 76.6 & -0.4 \\
\hline Laureles & 70.2 & 69.6 & -0.6 \\
\hline America & 62.0 & 61.9 & -0.1 \\
\hline Belen & 55.9 & 57.4 & +1.5 \\
\hline Candelaria & 56.7 & 56.4 & -0.3 \\
\hline Guayabal & 50.6 & 52.3 & +1.7 \\
\hline Buenos Aires & 46.7 & 49.9 & +3.2 \\
\hline Medellín urbano & 47.3 & 49.3 & +2.0 \\
\hline Castill & 47.0 & 48.1 & +1.1 \\
\hline Robledo & 43.4 & 46.1 & +2.7 \\
\hline Aranjuez & 40.7 & 44.1 & +3.4 \\
\hline Doce de Octubre & 38.6 & 40.8 & +2.2 \\
\hline San Javier & 37,0 & 40.4 & +3.4 \\
\hline Villa Hermosa & 36.5 & 39.7 & +3.2 \\
\hline Manrique & 35.6 & 37.5 & +1.9 \\
\hline Santa Cruz & 33.8 & 37.1 & +3.3 \\
\hline Popular & 31.5 & 34.8 & +3.3 \\
\hline
\end{tabular}

A consistent, marked improvement is to be observed in terms of education, with consecutive administrations keeping the level of investment in this sphere high (Table 5). Permanent improvement is observed especially in terms of school attendance at 16 y.o., less for the same indicator for children aged 15. But, while under-investment was an issue at the beginning of the 21st century, the motivation to go to school was also low in poor neighbourhoods. Fajardo's campaign 'Medellín, the most educated' not only set education as a priority for the administration, but also exerted its impact as regards steady growth in people's personal motivations to keep learning. A general improvement in the economic situation plus other social programmes both contributed.

A very important initiative and impressive undertaking has been the construction of social housing in Medellín. This was a necessity, given the presence of thousands displaced by the armed conflict arriving in the city every year. But it was also needed for those displaced by new developments, or moved out of zones facing a high geological risk of disaster. This leaves social housing inseparable from the transformation the city has been going through. In Colombia, city administrations do not construct social housing themselves, but contract out to private companies, which design and implement the relevant housing projects. The highest concentration of social housing is present near the city limits of western Medellín, in the Ciudadela de Nuevo Occidente. This is in fact one of Colombia's largest social housing projects, with 112,000 inhabitants foreseen. Many researchers (Uribe Tami, 2019; Velázquez Higuita, 2012) join inhabitants in pointing to serious faults and deficiencies with this project. 
Table 5. Educational indices and investment

\begin{tabular}{|c|c|c|c|c|c|c|c|c|c|c|c|}
\hline \multicolumn{1}{|c|}{ Indicator } & $\mathbf{2 0 0 8}$ & $\mathbf{2 0 0 9}$ & $\mathbf{2 0 1 0}$ & $\mathbf{2 0 1 1}$ & $\mathbf{2 0 1 2}$ & $\mathbf{2 0 1 3}$ & $\mathbf{2 0 1 4}$ & $\mathbf{2 0 1 5}$ & $\mathbf{2 0 1 6}$ & $\mathbf{2 0 1 7}$ & $\mathbf{2 0 1 8}$ \\
\hline School attendance at 15 y.o. (\%) & 88.7 & 92.6 & 98.3 & 99.6 & 97.5 & 94.4 & 96.2 & 95.8 & 93.9 & 92.2 & 90.9 \\
\hline School attendance at 16 y.o. (\%) & 70.9 & 74.2 & 78.3 & 81.5 & 82.4 & 79.7 & 78.3 & 77.1 & 79.0 & 79.3 & 77.9 \\
\hline $\begin{array}{l}\text { Public investment in education } \\
\text { (\% of total public investment) }\end{array}$ & 35.5 & 27.0 & 23.1 & 23.1 & 31.2 & 25.9 & 26.8 & 25.1 & 30.1 & 23.7 & 23.2 \\
\hline
\end{tabular}

Source: MCV (2018).

Contractors obliged to build housing, but not checked out well enough by the state, have elected to pay little or no attention to public spaces, which are therefore very few and far between. This strongly impacts on the quality of inhabitants' lives, and on their ability to form communities. They move their small workshops into their apartments, also meeting and socialising there, with the effect that chances of community ties being extended remain limited. As the original author's study shows, residents of social housing are less likely than those who live in traditional neighbourhoods to 'hang out' with others in close proximity to their homes. Either people stay at home, or they truly go outside, and hence further from home (Table 6). This kind of situation generates, rather than combats, marginalisation, not so much because of geographical distance from the centre, but more because of the lack of a cultural offer and centrality within neighbourhoods.

The slogan of this huge undertaking was 'before they start to dream, people need a place to sleep', and in a sense it has come back to haunt its authors, as Nuevo Occidente is really not much more than a dormitory. What is more, such projects are so extensive that they may transfer or reproduce patterns of spatial segregation, rather than truly combating this problem.

Table 6. Place where dwellers spend their free time during weekdays and weekends, by type of settlement: a traditional neighbourhood versus social housing

\begin{tabular}{|c|c|c|}
\hline \multicolumn{3}{|c|}{ Question 1: Where do you spend most of your free time during the week? } \\
\hline Place & $\begin{array}{l}\text { Traditional neighbourhood } \\
\text { (barrio) }\end{array}$ & Social housing \\
\hline At home & $60.6 \%$ & $65.7 \%$ \\
\hline Outside home, but in close proximity to it & $24.5 \%$ & $14.3 \%$ \\
\hline $\begin{array}{l}\text { Outside home, in various places, but outside the } \\
\text { neighbourhood }\end{array}$ & $10.6 \%$ & $20.0 \%$ \\
\hline Other situation & $4.3 \%$ & $0.0 \%$ \\
\hline Base: (number of interviews) & 188 & 70 \\
\hline \multicolumn{3}{|l|}{ Chi-square: 9.019, df: 3, sig. 0.029} \\
\hline \multicolumn{3}{|c|}{ Question 2: Where do you spend most of your free time during the weekend? } \\
\hline Place & $\begin{array}{l}\text { Traditional neighbourhood } \\
\text { (barrio) }\end{array}$ & Social housing \\
\hline At home & $38.8 \%$ & $40.0 \%$ \\
\hline Outside home, but in close proximity to it & $27.1 \%$ & $12.9 \%$ \\
\hline $\begin{array}{l}\text { Outside home, in various places, but outside the } \\
\text { neighbourhood }\end{array}$ & $29.8 \%$ & $42.9 \%$ \\
\hline Other situation & $4.3 \%$ & $4.3 \%$ \\
\hline Base: (number of interviews) & 188 & 70 \\
\hline
\end{tabular}

Source: author's own study. 
Overall, even if Medellín's inhabitants are experiencing an improvement in their quality of life, this can be considered a slow and not especially stable process. Furthermore, it relates mostly to the macroeconomic situation in Colombia as a whole - to the extent that similar processes may be observed in other large Colombian cities. Furthermore, many urban-transformation projects led to involuntary relocation of dozens of families, with many going on to inhabit the aforementioned social-housing districts, which can be though to produce more in the way of marginalisation than inclusion.

Finally, looking back at the optimism and enthusiasm of the founding fathers of social urbanism, it is really hard to find a link between monumental works of architecture and actual improvement of households' economic and social statuses. Equally, there are indeed spheres in which an impact is visible.

\section{International recognition for Medelllín}

Once Medellín had taken (in 2013) the title 'most innovative city in the world', as awarded by the Urban Land Institute, it became 'fashionable' for others to also grant it awards.

In the last five years alone, rather an armful of awards has been handed over, including:

- in 2014: The best city to live in, in Latin America (granted by Indra - a global technology and innovation company),

- in 2015: the Inter-American Award on Innovation in Effective Public Management (as granted by the Organization of American States),

- in 2016: the Lee Kuan Yew World City Prize (granted by the Urban Redevelopment Authority of Singapore and the Centre for Livable Cities, Singapore),

- in 2017: the Place Marketing Forum Award in the category Social Innovation and Territorial Resilience (as granted by Aix-Marseille University in France),

- in 2018: NovaGob Exelencia: Women in public sector (as granted by Novagob. lab Latin America),

- in 2019: Medellín, a Learning City awarded by UNESCO,

- in 2019: Medellín as a Centre for the Fourth Industrial Revolution in Latin America (as awarded by the World Economic Forum).

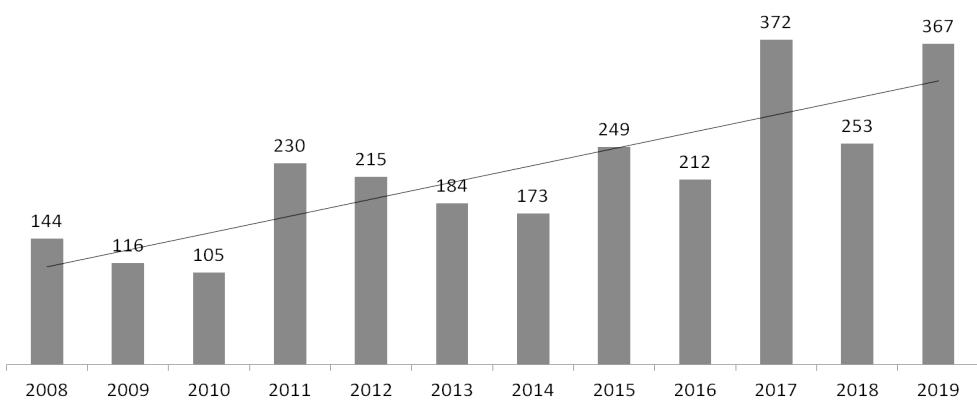

Figure 2. Foreign investment in Medellín (millions of USD) Source: ACl Medellín.

While the awards were mostly granted for the achievements in social urbanism and for territorial interventions, their impacts lay in international fame and recognition, serving as evidence of the city's success in the neoliberal 'market of the cities'. Medellín seized the opportunity and did 
its best to convert fame into measurable wealth. However, a definitely positive impact of the urban transformation is mainly experienced by entrepreneurs. During the past decade, and in the last 3 years in particular, foreign direct investment in the city has multiplied.

The story of Medellín's success and miraculous progress is thus being simplified (one might say 'dumbed down') on a daily basis; coloured and applied pragmatically in city marketing that targets both foreign investors and tourists; and with good results

\section{Final considerations}

The depth or profundity of Medellín's transformation is not as obvious as it might seem in the simplified form of communication fuelled intentionally by both those in administration and the private sector. What has indeed changed is the approach to land, which has been commodified in a dramatic fashion. A comparison with the 20th century shows how the image and brand of the city has become much more important. While 100 years ago and now, Medellín-dwellers might be equally concerned with the way their city is perceived, and in terms of their personal feeling of civic pride and identity, today's globalised world sees image as crucial when it comes to choosing a place for a visit, or for locating investment. In a cluttered media, any story being told must look simple, and be outstanding. And this is the kind of message about Medellín that is now 'out there'.

The international recognition achieved by inhabitants of Medellín (and the associated increase in self-esteem) is an unquestionable achievement of this urban transformation. Social programmes directed at marginalised inhabitants have also brought positive effects, if ones that fall short of either the miraculous or the revolutionary. In contrast, business has been able to develop dynamically (once again), making it absolutely clear how social urbanism has proved beneficial to economic elites. At the same time, journalists and academics have recently become more cautious in linking social urbanism with reduced violence.

Thus, in the wake of the initial outburst of admiration from a few years ago, a time for 'healthy scepticism' has arrived. A key point raised is that the architectural masterpieces involved in social urbanism were actually a sort of an 'urban makeup' that beautified poverty (Reed, 2014, April 15). In advance of the World Urban Forum (2014), dwellers of poor neighbourhoods were asked to paint their homes in bright colors (Flint, 2014). Thus, while the transformation as a whole was supposed to generate a definitive break with the isolation of the poor, and to put an end to the 'two cities', the whole discourse actually saw the poor converted into a tourist attraction painted in different colours, with the effect that they are once again objects... and a source of income for the social classes above them. Ironically, not every inhabitant of a poor neighbourhood can even in fact afford to use the cable car, even as that means of transport serves tourists as a very attractive and cheap way of going sightseeing in the 'exotic' slums. This aspect of city transformation which can be related to touristification has also been researched (Hernández García, 2013).

A further key observation has been that, while merciful, the investments in infrastructure lacked the authentic participation and involvement of the affected population, with the organised 'workshops of imaginaries' representing more of a façade than any true democracy. In truth, the main attention from the outset was on a transformation in public spaces that had its symbolism (given that, in a new and beautiful form, these would break with previous isolation caused by the violence and boost both security and integration). But this was then a great argument for investment in monumental - at times amazing - architecture, but not so much in housing, which will always and inevitably be far less spectacular. This just supports the contention that much of social 
urbanism's investment was oriented at gaining recognition and attracting positive attention (Sotomayor, 2015; Galindo Muñoz, 2018).

Fajardo used to speak about the 'change of skin' (cambio de piel) of Medellín, but in fact this may have been little more than 'skin-deep'. The city may look entirely different, but its entrenched class structure remains just that. In truth, that is the case for Colombia as a whole, but it can still be seen readily enough in Medellín, which still seems to be 'owned' by the economic and political elites. Ultimately then, after the violent rupture of the 1980s and 1990s (which paradoxically meant an actual break with the ordering of the social classes), Medellín has returned to a state recalling that from a century ago. Back in place is a solid entrepreneurial and political class that cares to transfer resources down to the bottom of the social ladder, entirely in line with its own visions generated and decisions taken.

\section{Acknowledgments}

Research by the author has gained funding from Poland's National Science Centre (NCN), under Contract No. UMO-2015/19/N/HS6/00624.

\section{References}

AP (2019). ArquitecturaPanamericana.com. Retrieved from http://arquitecturapanamericana.com/ proyecto-urbano-integral-pui-nororiental-comunas-1-y-2-areas-de-influencia-sistema-metrocable-Medellín/

Baker, S. (2019, November 3). Here's what it's like to ride Medellin's famous cable car system, which helped transform the Colombian city from the world's most dangerous to the most innovative. Business Insider. Retrieved from https://www.businessinsider.com/Medellín-cable-cars-what-like-touse-transformed-city-colombia-2019-10?IR=T

Ballas, D. (2013). What makes a 'happy city'? Cities, 32, 39-50. http://dx.doi.org/10.1016/j.cities.2013.04.009

Betancur, J. (2007). Approaches to the regularization of informal settlements: The case of PRIMED in Medellín, Colombia. Global Urban Development, 3(2), 1-15.

Borja, J. (2001). El gobierno del territorio de las ciudades latinoamericanas. Barcelona: IIGOV.

Brand, P. (2009). ¿Urbanismo social o seguridad democráticaen las ciudades? Estrategias gubernamentales en conflicto. Retrieved from https://www.ucl.ac.uk/bartlett/development/sites/bartlett/files/ brand-2009.pdf

Brand, P., \& Dávila, J. D. (2011a). Aerial cable-car systems for public transport in low-income urban areas: lessons from Medellín, Colombia. Conference Paper, $3^{\text {rd }}$ World Planning Schools Congress, Perth.

Brand, P., \& Dávila, J. D. (2011b). Mobility innovation at the urban margins. City, 15(6), 647-661. https:// doi.org/10.1080/13604813.2011.609007

CNMH (2017). Medellín: Memorias de una guerra urbana. Bogotá: Centro Nacional de Memoria Historica, Corporación Región, Ministerio del Interior, Alcaldía de Medellín, Universidad EAFIT, Universidad de Antioquia.

DANE (2019). Informacion para todos. Retrieved from www.dane.gov.co

Dávila, J. D., \& Daste, D. (2012). Medellín's aerial cable-cars: social inclusion and reduced emissions. London: Development Planning Unit, University College London. Retrieved from https://www.ucl. ac.uk/bartlett/development/sites/bartlett/files/davila-daste-2012-unep.pdf

Dunn, E. W., Wilson, T. D., \& Gilbert, D. T. (2003). Location, Location, Location: The Misprediction of Satisfaction in Housing Lotteries. Personality and Social Psychology Bulletin, 29(11), 1421-1432. https:// doi.org/10.1177/0146167203256867 
Duque Franco, I. (2015). La cultura como estrategia de transformación y promoción urbana en Bogotá y Medellín. Revista de Geografía Norte Grande, 61, 25-43.

Echeverri, A., \& Orsini, F. M. (2010). Informalidad y Urbanismo Social en Medellín. In A., Echeverri \& F. M., Orsini (Eds.). Medellín, Medioambiente, Urbanismo y Sociedad (pp. 13-24). Medellín: Fondo Editorial Universidad Eafit.

Echeverri, A. (2019). I'm reducing crime with urban planning. Retrieved from https://www.shamengo. com/en/pioneer/124-alejandro-echeverri/

Fajardo, S. (2017). El poder de la decencia. Bogota: Editorial Planeta Colombiana.

Flint, A. (2014). Is There a Medellín Hype Machine? CityLab. Retrieved from https://www.citylab.com/ design/2014/04/Medellín-hype-machine/8856/

Franz, T. (2017). Urban governance and economic development in Medellín: An 'urban miracle'? Latin American Perspectives, 44(2), 52-70. https://doi.org/10.1177/0094582X16668313

Galindo Muñoz, O. (2018). El espacio público en la Medellín Competitiva. In S., Roldán Gutierrez \& L. F., Londoño (Eds.). Ciudadania Antes Que Ciudad (pp. 95-132 ). Medellín: Grupo Urbano Medellín.

García, Y. C. (2018). Extorsión: el "gran negocio" del crimen organizado en Medellín. Agencia de Prensa IPC. Retrieved from http://www.ipc.org.co/agenciadeprensa/index.php/2018/11/23/extorsion-el-gran-negocio-del-crimen-organizado-en-medellin/

Gehl, J. (2011). Life between Buildings: Using Public Space. New York: Van Nostrand Reinhold.

Gehl, J., \& Rogers, R. (2013). Cities for People. Washington, DC: Island Press.

Glass, R. (1964). Introduction to London: aspects of change. London: Centre for Urban Studies.

Gonzalez Escobar, L. (2014). La transformación urbana de Medellín: el tranvía de Ayacucho. Revista Universidad de Antioquia, 314, 95-101.

Hernández-García, J. (2013). Slum Tourism, City Branding and Social Urbanism: The Case of Medellin, Colombia. Journal of Place Management and Development, 6(1), 43-51. https://doi. org/10.1108/17538331311306122

Insight Crime (2019). Medellín Sees Murders Rise After Years of Declining Violence. Insight Crime. Retrieved from https://www.insightcrime.org/news/analysis/organized-crime-Medellín-murders/

Jover, J., \& Díaz-Parra, I. (2019). Gentrification, transnational gentrification and touristification in Seville, Spain. Urban Studies. https://doi.org/10.1177/0042098019857585

Kalmanovitz, S. (Ed.) (2015). Breve historia económica de Colombia. Bogotá: Utadeo.

KienyKe (2017). Medellín, ċla tercera más densamente poblada del mundo? Retrieved from http://www. kienyke.com/noticias/Medellín-la-tercera-mas-densamente-poblada-del-mundo

Leszczyński, A. (2016). Eksperymenty na biednych. Polityczny, moralny i ekonomiczny spór o to, jak pomagać skutecznie. Warsaw: Wydawnictwo Krytyki Politycznej, Instytut Studiów Politycznych PAN.

MacLean, K. (2014). The 'Medellín Miracle': The politics of crisis, elites and coalitions. London: Birkbeck College, University of London.

Mahoney, J. (2002). The Legacies of Liberalism: Path Dependence and Political Regimes in Central America. Baltimore, MD: Johns Hopkins University Press.

Marans, R. (2012). Quality of Urban Life Studies: An Overview and Implications for Environment-Behaviour Research. Social and Behavioral Sciences, 35, 9-22. https://doi.org/10.1016/j.sbspro.2012.02.058

Margolis, M. (2010, July 16). Colombia becomes a Latin American star. Newsweek. Retrieved from https://www.newsweek.com/colombia-becomes-latin-american-star-74911

Martin, G. (2012). Medellín. Tragedia y Resurrección. Mafia, ciudad y estado 1975-2012. Bogota: Planeta Colombiana.

MC (2019). MedellinColombia.co. Retrieved from https://www.medellíncolombia.co/getting-around/ Medellín-metro/

MCV (2018). Informe de Calidad de Vida de Medellín, 2018. Medellín Cómo Vamos. Retrieved from https://www.medellincomovamos.org/informe-de-calidad-de-vida-de-medellin-2018

Medellín (2008). Medellín: transformación de una ciudad. Medellín: Alcaldía de Medellín, Banco Interamericano de Desarrollo.

Moncada, E. (2016). Urban violence, political economy, and territorial control. Insights from Medellín. Latin American Research Review, 51(4), 225-248. https://doi.org/10.1353/lar.2016.0057 
Montgomery, C. (2013). Happy City: Transforming Our Lives through Urban Design. New York, NY: Macmillan Publishers.

Museo Casa de la Memoria (2018). Medellín/es 70, 80, y 90. Memorias por contar. Museo Casa de la Memoria. Retrieved from https://www.museocasadelamemoria.gov.co/events/medellines-70-80-90/

Naranjo, G. G, \& Villa, M. M. I. (1997). Entre Luces y Sombras. Medellín: espacio y politicas urbanas. Medellín: Corporación Región.

OECD (2006). OECD Territorial Reviews. Competitive Cities in the Global Economy. Paris: OECD.

Ortiz, C., \& Liebherr, L. (2014). Medellín: hacia la construcción de un modelo de estrategias para la equidad territorial? In J. M., Navarrete Heredia, M. M., Ángel Bernal \& M. G., Donovan (Eds.). Equidad Territorial en Medellín. La Empresa de Desarrollo Urbano EDU como motor de la transformación urbana (pp. 31-59). Medellín: Empresa de Desarrollo Urbano.

Osorio Gaviria, D. (2014). Moravia: The story of a slum on a hill of garbage. Human Settlements. Retrieved from https://issuu.com/dannyandresosoriogaviria/docs/moravia_the_story_of_a_slum_on_a_hi

Party, D. (2008). The Miamization of Latin-American Pop Music. In I., Corona \& A. L., Madrid (Eds.). Postnational Musical Identities: Cultural Production, Distribution and Consumption in a Globalized Scenario (pp. 65-80). Lanham, MD: Lexington Books.

Patiño Villa, C. (2015). Medellín: Territorio, Conflicto y Estado. Análisis geostratégico urbano. Bogota: Editorial Planeta Colombiana.

Peña Gallego, L. E. (2011). Las bibliotecas públicas de Medellín como motor de cambio social y urbano de la ciudad. BiD: textos universitaris de biblioteconomia i documentació, 27, pp. 11.

Reed, D. (2014, April 15). Medellín: Miracle or Marketing Ploy? This Big City. Retrieved from https:// thisbigcity.net/medellin-miracle-or-marketing-ploy/

Reimerink, L. (2017). Planners and the Pride Factor: The Case of the Electric Escalator in Medellín. Bulletin of Latin American Research, 37(2), 191-205. https://doi.org/10.1111/blar.12665

Roldan, M. (1997). Citizenship, Class and Violence in Historical Perspective: The Colombian Case. Unpublished manuscript.

Salazar Jaramillo, A. (Ed.) (2011). Laboratorio Medellín, Catálogo de diez prácticas vivas. Medellín: Alcalde Alcaldia de Medellín, ACI, BID, UN Habitat. Retrieved from https://acimedellin.org/wp-content/ uploads/2017/06/laboratorio-medellin-acimedellin.pdf

Samper, J. (2017). Eroded resilience, informal settlements predictable urban growth implications for self-governance in the context of urban violence in Medellín, Colombia. UPLanD - Journal of Urban Planning, Landscape \& Environmental Design, 2(2), 183-206. https://doi.org/10.6092/25319906/5265

Sánchez-Jabba, A. (2014). La reinvención de Medellín. In L. A., Galvis (Ed.). Economía de las grandes ciudades en Colombia: seis estudios de caso (pp. 221-255). Bogota: Colección de Economía Regional, Banco de la República.

Sennet, R. (2019). Building and Dwelling. Ethics for the city. London: Penguin Books.

Sierra Noreña, J. P. (2016). Marketing urbano, forma de gobierno neoliberal en la ciudad de Medellín. Iconofacto, 12(19), 124-153. http://dx.doi.org/10.18566/iconofact.v12.n19.a05

Soto, A. (2012). Memorias de la violencia paramilitar en Medellín. Kogoró: Revista de estudiantes de Antropología, 4, 65-72.

Sotomayor, L. (2015). Equitable planning through territories of exception: the contours of Medellín's urban development projects. International Development Planning Review, 37(4), 373-397. https:// doi.org/10.3828/idpr.2015.23

Sternberg, E. (2010). Healing Spaces: The Science of Place and Well-Being. Cambridge, MA: Belknap Press.

UN (2017). HABITAT III Regional Report Latin America and the Caribbean. United Nations. Retrieved from https://unhabitat.org/sites/default/files/documents/2019-05/habitatiii-regional-report-lac.pdf

UN (2018). The World's Cities in 2018. United Nations. Retrieved from https://www.un.org/en/events/ citiesday/assets/pdf/the_worlds_cities_in_2018_data_booklet.pdf

Uribe Tami, M. F. (2019). Vivienda digna en las políticas públicas en Colombia. Territorios en formación, 15, 6-24. https://doi.org/10.20868/tf.2019.15.3984 
Valins, S., \& Baum, A. (1973). Residential Group Size, Social Interaction, and Crowding. Environment and Behavior, 5(4), 421-439. https://doi.org/10.1177/001391657300500404

Velásquez Higuita, C. M. (2012). Vivienda social y ordenamiento territorial en Medellín durante el periodo 2006- 2011. Pasos hacia la segregación residencial socioeconómica. Territorios, 27, 181-197. 